\title{
Structural Stability of Chromosomes in Rice (Oryza sativa L.) Plants Regenerated from Somatic Tissue Culture
}

\author{
Soryu NishibaYaShi and Junko KaERIYAMA \\ Plantech Research Institute, clo MCI Research Center, 1000 Kamoshida-cho, \\ Midori-ku, Yokohama 227, Japan
}

(Received December 21, 1985)

(Accepted January 25, 1986)

Phenotypic variations have been more frequently observed in rice plants regenerated from cultured cells. ${ }^{1-10)}$ Several of these phenotypic variations were found to result from gene mutations showing mendelian segregation pattern. ${ }^{6,8-10)}$ Cytological investigations revealed that the number of chromosome varies highly in anther-derived calli ${ }^{4,5}$ ) and in their regenerated plants. ${ }^{2,4,5)}$ These observations indicated that genetic variations may arise during cell culture. These cytological studies, however, have been limited to the study of the chromosome number, and not much information has been obtained on the chromosome structure.

The present study was to clarify the number and structure of chromosomes in rice plants regenerated from somatic tissue culture.

A cultivar of rice (Oryza sativa L.) 'Norin' 11 was used in the present study. Seeds were sterilized with $70 \%$ ethanol for $30 \mathrm{sec}$ and then with a solution of $0.6 \%$ sodium hypochlorite for $1 \mathrm{hr}$. They were then washed 3 times with sterile distilled water, and placed on MS medium solidified with $0.8 \%$ agar, supplemented with $2 \%$ sucrose, and adjusted to pH 5.3. Sterilized leaf base of 12 day-old seedlings were cut into sections of approx. $1 \mathrm{~mm}$ thickness. These sections were then placed on callus induction medium (MS medium with supplements of $1 \mathrm{mg} / \mathrm{l} 2$, 4-D, $3 \%$ sucrose, $\mathrm{pH}$ 5.3), solidified with $0.8 \%$ agar. After 4 weeks, the calli induced were further propagated for 3 weeks by transferring to the same medium. The propagated calli were then transferred to shoot induction medium (MS medium with supplements of $0.02 \mathrm{mg} / \mathrm{l}$ 2, 4-D, $2 \mathrm{mg} / l$ kinetin, $3 \%$ sucrose, $\mathrm{pH} 5.3$ ), solidified with $0.8 \%$ agar, and further transferred to fresh medium 3 weeks after the induction of shoot. Plantlets regenerated on the medium were transplanted into $100 \mathrm{ml}$ Erlenmeyer flasks containing $50 \mathrm{ml}$ of $0.5 \%$ Hyponex solution about 3 months after the initiation of callus induction. The growing conditions in the seedlings, calli and regenerated plants were kept constant under light (4,000 lux) for $16 \mathrm{hr}$ and under dark regime for $8 \mathrm{hr}$ at $25 \pm 1{ }^{\circ} \mathrm{C}$. Mitotic chromosomes were observed on meristematic tissues of root-tips in both seedlings and regenerated plants, as described previously. ${ }^{11)}$ The roottips were pretreated with $0.002 \mathrm{M}$ 8-hydroxyquinoline for $4 \mathrm{hr}$ at $20^{\circ} \mathrm{C}$ before they were fixed with acetic-alcohol (99\% ethanol: glacial acetic acid $=3: 1)$ for $1-24 \mathrm{hr}$ at $4-5^{\circ} \mathrm{C}$. After fixation the root-tips were washed with distilled water 3 times for 5 min each, and treated with an enzyme solution containing 4\% cellulase "Onozuka" RS (Yakult Honsha Co., Ltd.), 1\% pectolyase Y-23 (Seishin Pharmaceutical Co., Ltd.), $7.5 \mathrm{~mm} \mathrm{KCl}$ and $7.5 \mathrm{~mm}$ EDTA, and adjusted to $\mathrm{pH} 4.0$, for $30-60 \mathrm{~min}$ at $37^{\circ} \mathrm{C}$, and then washed 2 times with distilled water. Each of the root-tips was placed on glass slides and a drop of the fixative (acetic-alcohol) added to 

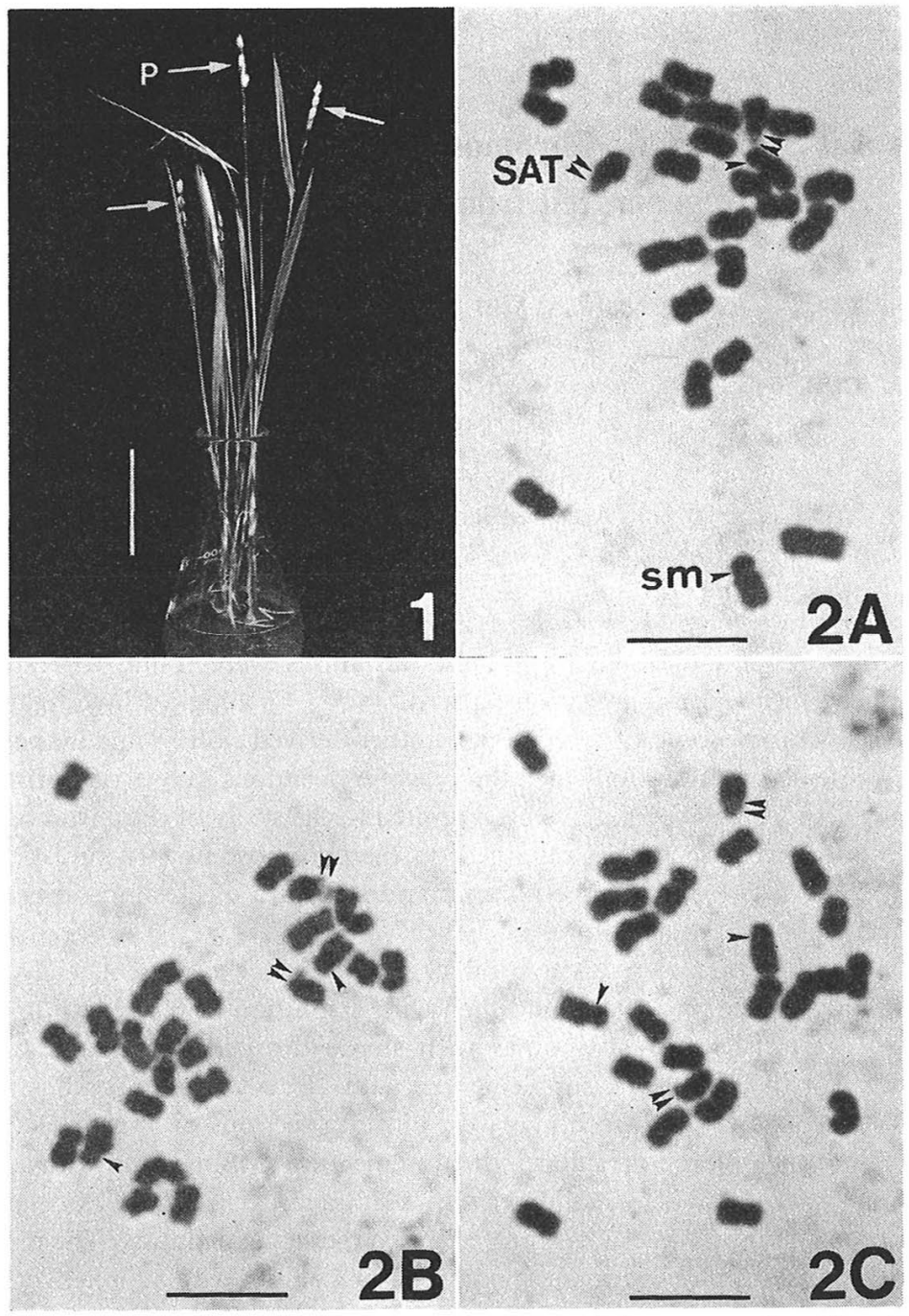

Fig. 1. Two month-old rice plants regenerated from somatic callus 3 , showing three regenerated plants with panicles. Arrows indicate panicles. Bar $=5 \mathrm{~cm}$.

Fig. 2. Metaphase chromosomes of root-tip cells in a seedling prior to callus induction $(\mathrm{A})$ and in plants 2-1 (B) and 3-3 (C) regenerated from callus 2 and callus 3 , respectively. The chromosome numbers in the seedling (A) and regenerated plants (B and C) are $24(2 n)$. The karyotype in regenerated plants ( $B$ and $C$ ) is the same as in the seedling (A). Arrow heads and double arrow heads indicate submedian and SAT chromosomes, respectively. No-marked chromosomes are median ones. $\mathrm{Bar}=5 \mu \mathrm{m}$. 
them. They were then gently cut into pieces with a pair of tweezers, air-dried for $10 \mathrm{~min}$ at room temperature, and stained with $2 \%$ aceto-orcein for $20 \mathrm{~min}$. Chromosomes were observed on 3-10 metaphase cells for both seedlings and regenerated plants.

A difference was observed in the potential of calli to regenerate panicle producing plants. A total of fifteen green plants were regenerated from four calli and grown in the culture room under the conditions described above. Six of the fifteen regenerated plants formed panicles with 3-19 grains for two to four months after explanting. In callus 3, for example all three regenerated plants formed panicles (Fig. 1), and in callus 1 and callus 4, one or two plants of the three plants regenerated from each callus formed panicles respectively, while in the case of callus 2 none of the six regenerated plants formed panicles. Seeds were formed in one plant regenerated from each of the callus 1, 3 and 4, respectively. Seed fertility was low in the range of $33-42 \%$. Plant height in plants with panicles was short in the range of 24.3 to 33.4 $\mathrm{cm}$. The karyotype in root-tip cells of the parent seedling prior to callus initiation comprised 22 median and 2 submedian chromosomes (Fig. 2A). Secondary constrictions were observed in two median chromosomes. Examination of chromosome number in the fifteen regenerated plants revealed them to have the same diploid chromosome number $(2 n=24)$ as parents (Figs. 2A-C). Aneuploid and polyploid plants were not observed. Chromosome structural changes such as dicentric, translocation and deletion were not observed. All regenerated plants exhibited similar karyotype to the parent karyotype (Figs. 2A-C).

Many authors have reported phenotypic variations for heading date, plant height, fertility and leaf color during tissue culture in rice (Oryza sativa L.). ${ }^{1-10}$ ) The percentage of phenotypic variants in regenerated rice plants was found to be $80 \%$ in anther cultures, ${ }^{4)}$ $77.9-100 \%$ in haploid somatic tissue cultures ${ }^{5}$ and $71.9-75.4 \%$ in diploid somatic tissue cultures. ${ }^{5,9,10)}$ Fukui (1983) has observed four mutations for early heading, short culm, sterility and albino in nine of twelve plants regenerated from a single callus of a rice seed. $\left.{ }^{9}\right)$ Chromosome numbers varied in the range of 10 and 114 in anther-derived calli, while haploids $(40 \%)$, diploids $(48.6 \%)$, triploids $(7.1 \%)$, tetraploids $(1.4 \%)$ and aneuploids $(2.9 \%)$ were found among the regenerated plants. ${ }^{4)}$ On the contrary, chromosome number in plants regenerated from somatic tissue culture was found to be $24(2 n)$ in a random sample of three of nineteen plants. ${ }^{1)} \quad$ But it is still possible that regenerated plants may have chromosomal abberation. In the present study, phenotypic characteristics in regenerated plants were not sufficiently investigated, however a difference was found among calli or regenerated plants in their potential to form panicles under the same growing conditions. Cytological observations showed the number and structure of chromosomes to be stable in fifteen plants regenerated from somatic tissue culture (Figs. 2A-C). This may suggest that some phenotypic variations in diploid somatic tissue culture could have resulted from gene mutation or chromosome rearrangement which cannot be identified by light microscopy.

\section{References}

1) Nishi, T., Y. Yamada, E. Takahashi, 1968. Nature, 219: 508-509.

2) Nishi, T., S. Mitsuoka, 1969. Jpn. J. Genet., 44: 341-346.

3) Niizeki, H., K. Oono, 1971. Les Cultures de Tissue de Plantes, 193: 251-257.

4) Oono, K., 1975. Bull. Nat1. Inst. Agric. Sci. Ser. D, 26: 139-222.

5) Oono, K., 1984. Plant Tissue Cult. Lett., 1: 2-7.

6) Oono, K., 1985. Mol. Gen. Genet., 198: 377-384.

7) Henke, R. R., M. A. Mansur, M. J. Conttantin, 1978. Physiol. Plant., 44: 11-14.

8) Suenaga, K., E. M. Abrigo, S. Yoshida, 1982. IRRI Research Paper Ser., No. 79: 1-11.

9) Fukui, K., 1983. Theor. Appl. Genet., 65: 225-230. 
10) Zong-xiu, S., Z. Cheng-zhang, Z. Kang-le, Q. Xiu-fang, F. Ya-ping, 1983. Theor. Appl. Genet., 67: 67-73.

11) Nishibayashi, S., 1985. Jpn. J. Breed. 35 (Suppl. 1): 318-319.

\title{
《和文要約》
}

\section{イネの体細胞組織培養で再生した植物体の染色体構造の安定性}

\author{
西林双龍，帰山淳子 \\ 㧣植物工学研究所
}

イネ(農林 11 号)の幼葉基部体細胞組織由来カルスから再生した 15 植物で染色体の数と構造を観察し た. その結果, 再生した 15 植物のすべてが 2 倍体 $(2 n=24)$ で, しかも正常な核型 $(20$ 中部動原体的染 色体 +2 次中部動原体的染色体 +2 SAT 染色体) を示した. 